\title{
Mobile Banking Applications: Consumer Behaviour, Acceptance and Adoption Strategies in Johannesburg, South Africa (RSA)
}

\author{
Garth Andrew Balabanoff
}

Bcom Honours (Marketing), School of Economics and Business Sciences, University of the Witwatersrand, Johannesburg

Doi:10.5901/mjss.2014.v5n27p247

\begin{abstract}
There has been a complete disparity in the number of cell phone subscribers when compared to fixed line users in South Africa (referred to as Republic of RSA or RSA). In 2011, results revealed that 29 million South Africans use mobile phones compared to only 5 million using fixed lines (Brown, Cajee, Davies, \& Stroebel,2003; Lascaris,2012). It is because of this increased and saturated mobile market that we have seen the extreme growth of mobile applications. This increase is coupled with several benefits that mobile applications bring to the consumer, such as increased functionality, productivity improvements and entertainment (Pranata, Athauda, \& Skinner, 2013). Although adoption strategies around internet banking and cell phone banking have been explored in various parts of the world, adoption strategies specifically around mobile banking applications or "mbapps" have not been vastly researched (Jaruwachirathanakul \& Fink, 2005). As such, this study focused on examining consumer behaviour and acceptance towards adopting mbapps in Johannesburg RSA, where mbapps are in an emerging phase, but offer potential benefits to both consumers and industry at large. A quantitative research methodology was used for this research. Self-administered quantitative questionnaires were distributed at the University of Witwatersrand as well as to individuals within the Johannesburg area aged between 18 and 60 years. A pilot study of 30 respondents was conducted to ensure validity and reliability of the questionnaire. Following this, the research was then conducted to a sample size of 373 respondents. Due to time constraints, this study made use of convenience sampling. Data collected from the questionnaires was analysed using statistical analysis to investigate the relationship between the variables used in the research model, this being a modified version of the Decomposed Theory of Planned Behaviour model - The decomposed TPB model is successful in predicting and explaining human behaviour across various platforms and breaking outcomes down into specific dimensions. In addition, the decomposed TPB model is most suitable for steering decision makers towards the implementation of innovations. The decomposed TPB model will provide insight into understanding consumers'individual attitudes, subjective norms and perceived behavioural control, which ultimately influences the likelihood of consumers using mbapps. From the findings, it can be concluded that the results of this study support the proposed conceptual model. The findings of this research, which was focused towards, Attitude, Perceived Behavioural Control and Subjective Norms do have a significant relationship on the intention to adopt mbapps. In terms of the hypotheses set and tested, all resulted as postulated. In conclusion to this study the contribution of this research provides the banking industry, marketers and academics with the factors that encourage consumers to adopt mbapps and to utilise the research to exploit the conversion rate of customers towards adopting mbapps. Lastly this study adds value to not only the RSA market but potentially to other developing and developed countries through the recommendations made in chapter 5 . Decision makers are advised to take heed of the proposed strategies in maximising the rate of mbapps adoption.
\end{abstract}

\section{Introduction}

There has been a complete disparity in the number of cell phone subscribers when compared to fixed line users in RSA. In 2011, results revealed that 29 million South Africans or RSAns use mobile phones compared to only 5 Million RSAns using fixed lines(Brown et al.,2003; Lascaris,2012). It is because of this increased and saturated mobile market that we have seen the extreme growth of mbapps. This increase is coupled with several benefits that mobile applications bring to the consumer, such as increased functionality, productivity improvements and entertainment (Pranata et al., 2013).

Although adoption strategies around banking have been explored in various parts of the world, adoption strategies specifically around mbapps have not been vastly researched (Jaruwachirathanakul \& Fink,2005). As such, this study will focus on examining consumer behaviour and acceptance towards adopting mbapps in Johannesburg, RSA, where mbapps are in an emerging phase, but offer potential benefits to both consumers. The findings of this research will provide the banking marketers the factors that encourage consumers to adopt mbapps and to utilise the research to exploit the conversion rate of customers towards adoption. These findings will not only provide useful insights for the 
RSAn market, but also to developing countries.

Today's consumer is surrounded by technologies that engagement, exchanges, adoption, marketing and consumer behaviour attitudes. Previous research has shown that countries and organizations can be the catalysts and providers of modern technological tools, however unless consumers are willing to change behaviour and adopt, accept and utilise such tools the conversion rate shall be minimal. This landscape has ultimately created new opportunities and techniques in which consumers and organizations are able to interact (Al-Khouri,2013; Dapp, Stobbe, \& Wruuck,2012).

Mobile banking is said to be one of the fastest growing markets and is considered to have the same penetration rate as the introduction of cell phones (Alafeef, Singh, \& Ahmad,2011; Maduku,2012; Püschel, Mazzon, \& Hernandez,2010). As such business opportunities exist for innovative corporates and lateral thinking entrepreneurs. This study shall also provide other developing countries with findings to explore similar business prospects. In addition the academic will benefit from the literature review and shall be in a position to examine the factors influencing consumer behaviour towards adopting mbapps.

Since the introduction of mobile platforms the consumer market has grown exponentially; breaking technology adoption and usage records (Keshav,2005; Van Biljon \& Kotzé,2007). Complied in 2012, statistics show that mobile phone ownership and usage has encouraged global sales to total 1.75 billion mobile units along with 472 million smart phone sales against 2011's smart phone sales of 477 million units (Power,2013; vander Meulen \& Rivera,2013). In the last thirteen years, the global number of mobile phone subscribers has risen from 750 million, to 6 billion (Schmidt \& Cohen,2013). In Africa, the 2013 statistics indicate that there are 821 million mobile phone subscribers. These phenomenal sales have driven marketers and business leaders towards being focused on providing consumers with mbapps needs(Kamuti, 2013).

Mobile technology devices are a medium upon which consumers have become reliant, not only for communication but in addition for their daily lifestyle requirements. Mobile platforms such as smart phones and tablets have forced developers on every continent to create suitable applications to meet the needs of current consumers. This has steered marketers to refocus their marketing strategies to take advantage of consumer spending (Rodríguez-Ardura, Ryan, \& Gretzel, 2012).

In the interest of clarity, an app (abbreviation for "application") is a type of specific and customized software that is downloaded and installed on either smart phones or tablets. It allows the user to perform certain tasks and functions as well as access different types of information and services. Apps are designed to make life easier for users looking to perform certain tasks such as make a bank deposit, or book an airline or movie ticket. In addition, apps allow for easy access to information such as a weather forecast, or foreign exchange values. Apps advance and enhance the usability of a technological device such as apps that enable note-taking, or creation of presentations. Apps are also designed for pleasure such as gaming and editing of photographs.

In the last two decades there has been a noticeable shift in banking development channels, these being determined not only by banks or governments, but more specifically by consumers' attitudes and acceptance thereof. Globally, banks have had to constantly innovate to provide convenient and reliable services to their demanding and discerning customers (Bauer, Barnes, Reichardt, \& Neumann, 2005; Brown et al., 2003; Felix, Omolola, Irwin, \& Eric, 2012; Jaruwachirathanakul \& Fink, 2005; Pikkarainen, Pikkarainen, Karjaluoto, \& Pahnila, 2004; Tan \& Teo, 2000). This study's findings on mbapps consumer behaviour, acceptance and adoption strategies may provide useful insights for the RSAn market, other developing countries as well as other global players.

The use of technology in the banking environment has become more advanced over the last decade (Felix et al., 2012). Technology for use by the consumer has been limited to Internet and cell phone use (Jaruwachirathanakul \& Fink, 2005). As a result limited research is available around bmapps which gives rise to an opportunity of further study for bankers to make informed strategic decisions.

The emergence of this new banking platform, i.e mbapps, have come about through developers having to innovate due to a global landscape of increased crime, fraud, technological advancement and pressure from banks to cut costs for both the consumer as well as for the business. In addition, innovative bank marketers have been driven by consumers to constantly add value to their offerings. The ease of banking, being a primary value add, has steered bankers to better options. Mbapps achieve this objective as the consumer is now in a position to perform a multitude of banking functions. Bankers see this as another gateway for improving bottom line, as consumer convenience creates increased transactions (Virgillito, 2013).

This study identifies the problem that influences consumer behaviour and acceptance towards mbapps adoption in the RSAn market. 


\section{Literature Review}

During the literature review, studies focused on either internet, cell phone / mobile banking but not specifically on mbapps. A considerable amount of research done on the acceptance and adoption of internet, cell phone / mobile banking (Brown et al.,2003; Crabbe, Standing, Standing, \& Karjaluoto,2009; Dapp et al.,2012; Felix et al.,2012; Khraim, Shoubaki, \& Khraim,2011; Laforet \& Li,2005; Laukkanen,2007; Laukkanen, Sinkkonen, Laukkanen, \& Kivijarvi,2008; M. S. Lee, McGoldrick, Keeling, \& Doherty,2003; Luarn \& Lin,2005; Maduku,2012; Mlitwa \& Tshetsha,2012; Pedersen,2005; Polatoglu \& Ekin,2001; Püschel et al.,2010; Shambare,2011,2013; Sulaiman, Jaafar, \& Mohezar,2007; Suoranta \& Mattila,2004; Van Biljon \& Kotzé, 2007) in a multitude of countries which is available through various library journals, unpublished work, academic textbooks, organisational research, publications and government reports.

As the primary focus of the above studies were on mobile banking and internet banking and not on mbapps; it was therefore evident that these studies could not demonstrate sufficient information on consumer behaviour, acceptance and the adoption thereof in the RSAn mbapp context.

Having said this, an opportunity exists to explore the platform of consumer behaviour, acceptance and adoption strategies around mbapps. Once understood, a clear understanding of these factors will enable decision makers with innovative opportunities to take advantage of organic growth and profiteering.

Mobile banking is one of the fastest growing markets with a minimum annual growth rate of at least $14 \%$ worldwide. Mobile banking is considered to have the same penetration rate as the introduction of cell phones. Mobile banking was introduced as a result of banks' added initiatives to increase customer satisfaction, convenience and access to services (Alafeef et al.,2011; Maduku, 2012; Püschel et al.,2010). In a report conducted by Juniper Research, it was identified that there are in excess of 300 million mbapp users and have forecasted that global adoption of mbapps will exceed the 530 million mark by the end of 2013 (Holden,2013).

Mobile banking presents new opportunities for the banking industry as it allows financial institutions and third parties to deliver financial services to both banked and unbanked customers, whether in RSA or abroad (Brown et al., 2003; Maduku, 2012; Mlitwa \& Tshetsha, 2012; Tiwari, Buse, \& Herstatt, 2006). Adding to this, mobile payments refer to the transfer of money through mobile devices (Mogale, 2013).

The attraction of cell phone / mobile banking, particularly in Africa where disparities between urban and rural are so blatant, is that financial activities such as fund transfers are attractive as these banking services can be performed at convenience (Amin,2008). Similarly Tashmia and Khumbula(2011) indicated that literally millions of individuals, not only in RSA but across the globe and specifically in emerging markets, were also excluded from banking services due to being part of the developing world. These populations are subjected to barriers of entry such as cost, location, education, access to tangible banking and transportation. With the advent of mobile banking, these individuals now have access to banking transactions and are able to participate in financial services. Due to the urban versus rural geography, the benefit minimizes time and distance challenges for the user as well as overhead and related costs for the provider.

Mbapps are defined as a process of executing financial functions and procedures through the use of a mobile device via specific software developed for this purpose. This specific software is commonly known as an "App" (Pousttchi \& Schurig, 2007).

According to Ivatury and Pickens(2006) in an article around mobile phone banking, an alliance between the telecommunication and banking industry took place. This collaboration gave way to the provision of mobile banking, giving consumers easy access to banking services which are becoming convenient.

RSA is referred to as a developing, third world country, it's banking infrastructure and services are amongst the best in the world. This includes extremely high standards, policies and procedures emanating from a highly regulated industry (Tashmia \& Khumbula,2011). A recent example is First National Bank (FNB) being acknowledged at the 2012 BAl-Finacle Global Banking Innovation Awards as the most innovative bank in the world. This award honoured FNB's culture of innovation and their advancement of retail banking. In addition, FNB was also noted for empowering all of its business units to be innovative (Bank Administration Institute, 2012; First National Bank, 2012).

The competitive nature of the banking industry's leaders has given rise to the development of innovative products and services within the financial sector of the RSAn banking industry. A primary objective of the RSAn major banks is to gain market share through the offering of new and innovative products that reach out specifically to all LSM (Living Standard Measures) groups. As a method of achieving this objective, banks are making access to banking transacting easy and affordable to all consumers. Mobile banking is leading the way towards achieving this strategy and is on a rapid growth path (Lawack-Davids, 2012; Tiwari et al., 2006).

RSA's four major banks, ABSA, FNB, Nedbank and Standard Bank, all provide cell phone / mobile banking services. Literature suggests that RSAn banking consumers favour conducting their banking transactions via cell phones 
more so than via any other method (Shambare,2013). A quarter of the RSAn banking market make use of internet banking as opposed to a third of this market who prefers mobile banking services (Shambare, 2013). 2011 statistics revealed that $21 \%$ of RSAns make use of cell phone banking services (Hutton, 2011; Mail \& Guardian.,2011), compared to $31 \%$ in 2012(Tubbs,2012; World Wide Worx,2012).

Recent statistics show that 63 million RSAn cell phone subscribers are registered on the RSAn mobile networks (The New Age, 2013). This is particularly interesting to note as the most recent census done in 2011 shows that RSA's population is 51.7 million (Statistics RSA, 2011).

Mobile banking presents an opportunity for financial institutions to extend banking services to new and existing customers. As such, traditional banking models did not fit the RSAn market. This in turn led to an innovative approach to develop suitable mobile banking products (S. Lee, Lee, \& Kim,2007).

With mbapp adoption strategies being in the developmental stage, there has been significant research on internet, cellphone and mobile banking, however none has been specifically conducted on mbapps in a RSAn context. Taking this into consideration, one needs to explore the various model frameworks around the drivers of electronic banking.

\section{Model Frameworks: An Overview}

Over many years, various intention-based models have been developed and tested to determine the outcomes of behaviour in and around IT space usage. These models have used behavioural intention to predict consumer usage, which in-turn, determined intention factors such as attitude, social influence and facilitating conditions (Taylor \& Todd, 1995).

These consumer behavioural studies, which are predominantly used to investigate customer acceptance in the internet banking environment, have focused on attitudes, behaviours and subjective norms which lead and drive consumer behaviour (Brown et al., 2003; Jaruwachirathanakul \& Fink, 2005; Pikkarainen et al., 2004; Shih \& Fang, 2004; Tan \& Teo, 2000). With the above in mind, there is sufficient evidence in the internet adoption arena but very little in the area of mbapps. As such, this study focuses on the attitudes, behaviours and subjective norms influencing consumer behaviour towards adopting mbapps in the RSAn market.

These seminal models include; Davis(1989) Technology Acceptance Model (TAM) (Davis, 1986; Pikkarainen et al., 2004), Theory of Reasoned Action (TRA) developed by both Fishbein and Ajzen(1975) and lastly Theory of Planned Behaviour (TPB) also known as the pure traditional Theory of Planned Behavior model (Ajzen, 1991), which was an extension of the TRA model as well as the Taylor and Todd(1995) decomposed TPB model.

\subsection{Technology Acceptance Model (TAM)}

The Technology Acceptance Model (TAM) originally developed by Fred Davis (Davis, 1986, 1989), which was based on Fishbein and Ajzen(1975)'s Theory of Reasoned Action model (TRA), is a model which assumes that ones social behaviour is driven by ones behavioral attitude. In other words, one's attitude and intention to use a specific technology platform (Davis., Bagozzi, \& Warshaw, 1989). The TAM model is well known for its ability to predict user acceptance and use of new information technology within an organisation (Davis, 1986, 1989; Davis. et al., 1989). The TAM model is typically used to predict usage and adoption rates of new technology within information systems (IS) research (MartiParreño, Sanz-Blas, Ruiz-Mafe, \& Aldás-Manzano, 2013).

Taking this into consideration and evidenced through prior research (Taylor \& Todd, 1995), the TAM model has emerged as a powerful method to portray the framework of system usage through beliefs based on two factors;

1. the perceived ease of use, and

2. the perceived usefulness of information systems

According to Taylor and Todd (1995), this model is the more preferable model when wanting to determine the prediction of usage. The original TAM model is represented below: 
Figure 2.5: Technology Acceptance Model (TAM)

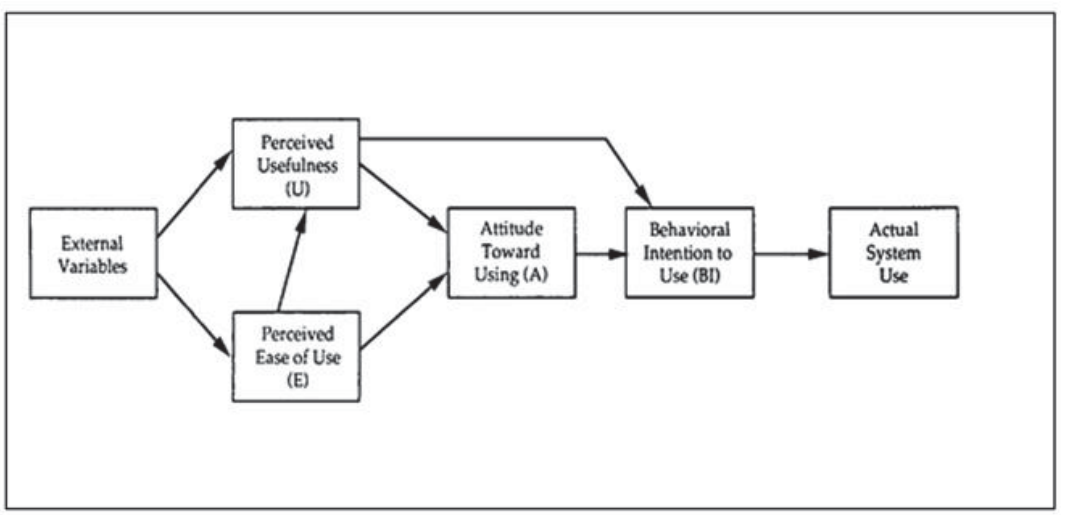

Source: Davis (1986)

\subsection{Theory of Reasoned Action (TRA)}

The Theory of Reasoned Action (TRA) was developed by Fishbein and Ajzen (1975). This model focused on four areas of behaviour namely: behavioural attitude, subjective belief norms, intention to use and actual use. The subjective belief norms were the differentiators between the TRA and TAM. The normative belief referred to individuals perceptions of the use of internet banking by others (Shih \& Fang, 2004).

In addition,Pikkarainen et al. (2004) state that the Theory of Reasoned Action is a theory that assumes the consumer behaviour is rational and consumers gather and analyze information systematically. It was also determined that based on this rational decision making, consumers would evaluate the risk of that action and decide on their next steps (McNeil, 2012). The original TRA model is represented below:

Figure 2.6: Theory of Reasoned Action (TRA)

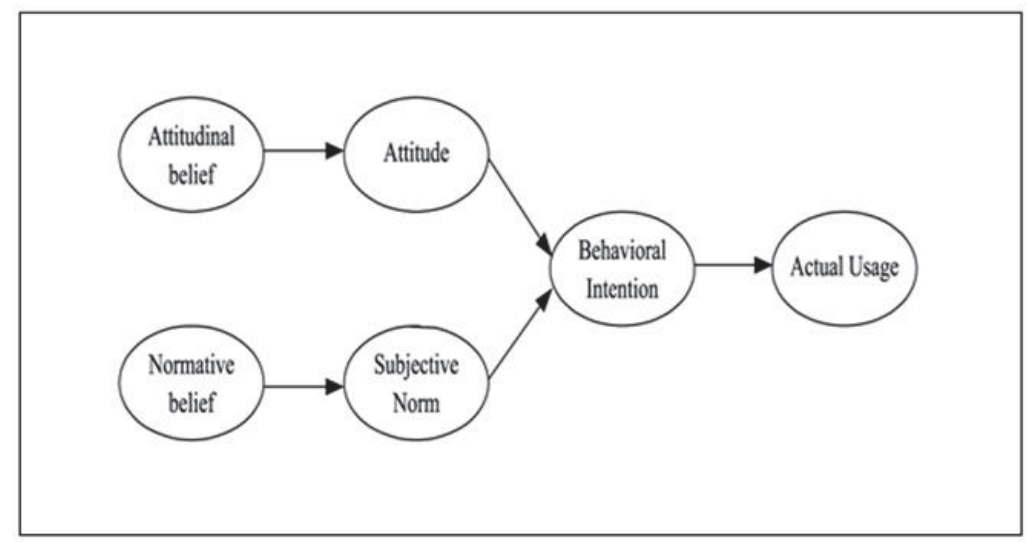

Source: Fishbein and Ajzen (1975)

\subsection{Theory of Planned Behaviour (TPB)}

The original version of the Theory of Planned Behaviour model developed by Icek Ajzen (1985), was an extension of TRA which accounted for conditions where individuals did not have complete control over their behaviour which was broken down further into one's intended behaviour and one's perceived behaviour. The TPB model focuses on behavioural intention being a function of attitude and subjective norm (Fishbein \& Ajzen, 1975; Taylor \& Todd, 1995).

In addition to the pure Theory of Planned Behaviour, the decomposed Theory of Planned Behaviour model was introduced. The decomposed TPB model is based on the original pure TPB model by Ajzen (1991). The decomposed TPB model uses constructs from Rogers (1983)'s theories of innovation which include relative advantage, complexity and 
compatibility. In addition to the innovation literature constructs, the decomposed TPB model includes subjective norms and perceived behavioral control.

Shih and Fang (2004) compared the TRA model to both the pure traditional TPB and the decomposed TPB. The research showed that the decomposed TPB model had a significant positive outcome for demonstrating behavioral intention, attitude and subjective norms than the TRA and the pure TPB models.

The decomposed TPB model is successful in predicting and explaining human behaviour across various platforms and breaking outcomes down into specific dimensions. Research indicates that the decomposed TPB model constructs provide leaders and marketing managers with an in-depth tool for understanding usage behaviour, intention and adoption towards system implementation (Jaruwachirathanakul \& Fink, 2005). Wang, Lin, and Luarn (2006) also make reference to the decomposed TPB model, which is an integrative model of the TAM, pure TPB and decomposed TPB models, stating that the decomposed TPB model is significantly better than the TAM model (Chau \& Hu, 2002; Chau \& Hu, 2001). Having said this, the decomposed TPB model delivers a holistic analysis of usage behaviour and intention, and is a more suitable guide than TAM to those searching for answers in the field of system implementation (Taylor \& Todd, 1995).

Jaruwachirathanakul and Fink (2005) showed in a comparison between the Technology Acceptance Model (TAM) applied in Finland, versus three tested models in Taiwan (the pure and decomposed forms of Theory of Planned Behaviour (TPB) as well as the Theory of Reasoned Action (TRA)) that both the TPB and TRA models were a good fit to the tested data of their study.

Based on the understanding of these models the research assignment will apply the decomposed TPB model. The decomposed TPB model is an appropriate model for investigating the adoption of mbapps. The decomposed TPB model is most suitable for steering decision makers towards these innovations. The decomposed TPB model will provide insight into understanding consumers' individual attitudes, subjective norms and perceived behavioural control, which ultimately influences the likelihood of consumers using mbapps (Taylor \& Todd, 1995).

According to Püschel et al. (2010) the decomposed TPB, as at 2010, was the most recent of innovation models developed, however, these have been primarily used in research. This study will use a modified version of the decomposed TPB model in order to fully meet the relevant and necessary objectives. A modified TPB model was used, as the original model included an additional construct, this being a measure on actual usage / adoption. Previous studies(Jaruwachirathanakul \& Fink, 2005; Khalifa \& Cheng, 2002; Ok \& Shon, 2006; Shih \& Fang, 2004; Tan \& Teo, 2000)have also made use of modified versions.

The justification for using a modified decomposed TPB model is based on establishing only the intent of the RSAn consumer to adopt mbapps and not to test the adoption thereof. In addition, Pedersen and Ling (2003) specifically emphasize that traditional adoption models that are studied within an information systems context, such as the decomposed TPB model, have the ability to be modified when applied to mobile adoption services, such as banking. As stated byTaylor and Todd (1995), the decomposed TPB model comprises three core factors (Attitude, Perceived Behavioural Control and Subjective Norms) that have a significant impact on human behaviour. Through this understanding marketers can potentially have clearer direction to their strategic objectives and reaching specific consumer markets. This modified version is depicted in Chapter 3, Research Methodology, however, the original pure decomposed TPB model by (Ajzen, 1991) is depicted below:

Figure 2.7: Pure Decomposed Theory of Planned Behaviour

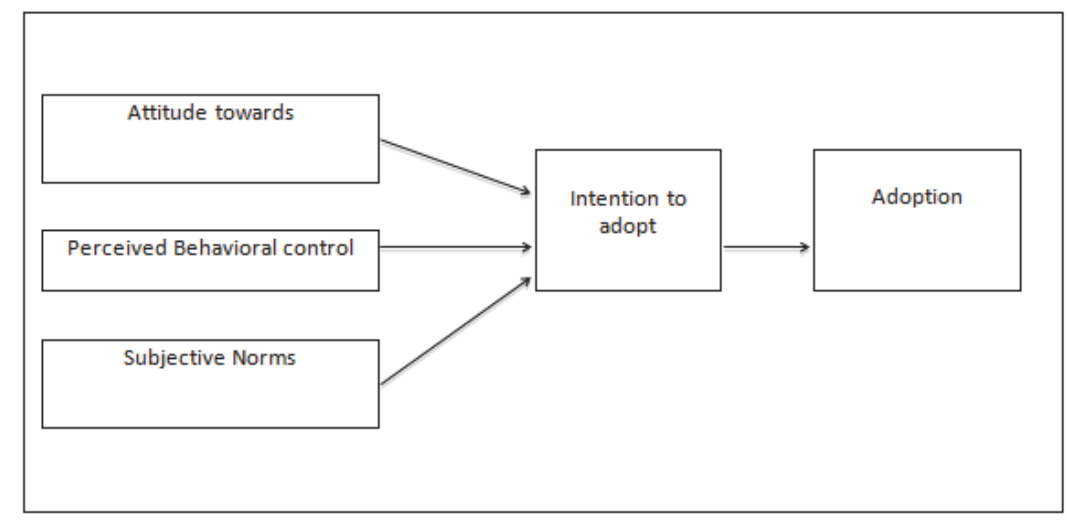

Source: Taylor and Todd (1995) 
As has been stated, the decomposed TPB model includes three main factors that influence human behaviour and adoption: Attitude, Perceived Behavioural Control and Subjective Norms.

Firstly, Attitude is viewed as one's perception, positive or negative, towards the adoption and usefulness of a specific innovation (Tan \& Teo, 2000).

Secondly, Perceived Behavioral Control, refers to the beliefs about having the available resources and opportunities to adopt a new innovation (Tan \& Te0, 2000).Lastly, Subjective Norms, refers to the social influences that surround an individual's intention to use a product, service or new innovation (Tan \& Teo, 2000).

These three main factors in the case of mbapps are explained below:

\subsubsection{Attitude}

Attitude, highlighted by Darwin in 1872, is a strong, influential and significant construct within the realms of consumer behaviour (Malhotra, 2005; Ndubisi \& Sinti, 2006).

An early definition of attitude described by seminal theorists, Fishbein and Ajzen (1975), refers to attitude as one's favourable or unfavorable predisposition towards a behaviour within a given context. That said, attitude is directly related to one's behavioural intention. For example, a person is more likely to have a predetermined behaviour towards something than a positive behaviour towards something (Ndubisi, 2004).

A further definition by Fishbein and Ajzen (1975) towards attitude was that "attitude is a learnt predisposition responding in a consistently favourable or unfavourable manner with respect to a given object". Furthermore, Lutz (1980) clarified that an 'object', when referred to in this context, is something such as a product brand (Proctor and Gamble), retail store (Mr Price), or in some instances an issue, person or behaviour in which consumers have a favourable or unfavorable attitude towards.

Attitude is also referred to as the degree to which one has an open disposition, leading to actual open behaviour. In other words, attitude explains a consumer's behavioural intentions. Thus, attitude is an important construct within understanding decision making from a marketing perspective (Lutz, 1980).

Researchers such as Taylor and Todd (1995) make reference to the fact that attitudinal belief within an innovation context, includes five perceived elements: relative advantage, complexity, compatibility, observability and trialabilty (Rogers, 1983).

Consequently, attitude in mbapps is referred to as one's perception of the usefulness of mbapps. These include the advantages, risks and privacy, and preferred features which shape attitude towards the adoption of mbapps (Taylor \& Todd, 1995).

\subsubsection{Perceived Behavioural Control}

In the context of mbapps, perceived behavioral control refers to an individual's belief that opportunities exist and will either aid or hinder an individual to utilise mbapps. Perceived Behavioural Control is influenced by two components namely; self-efficacy and facilitating conditions (Taylor \& Todd, 1995). Self-efficacy describes an individual's self-esteem towards being able to perform (Bandura, 1977, 1982). Hill, Smith, and Mann (1986) state that self-efficacy is a respectable construct in predicting intentions to use technology products. Therefore, a person that is technologically savvy is further inclined to adopt mbapps.

Facilitating conditions is defined as the degree to which resources are easily available in order to perform or partake in the behaviour (Triandis, 1979). Facilitating conditions in terms of mbapps can be broken down into specialized resources such as the ease of access, speed of use and associated costs (Taylor \& Todd, 1995).

\subsubsection{Subjective Norms}

Mbapps in RSA are relatively new. Subjective norms are likely to be influenced by the RSAn population as well as peer pressure of social groups - this understanding is put to test further in this study. Social groups can include family, friends and individuals within the same social realm(Ajzen, 1985). For example, a recommendation from a family member who has a positive attitude towards a mbapp the more likely another family member will use the application. Subjective norm is a powerful construct that aims to measure the social influences on an individual's behaviour (Lutz, 1980). Pedersen (2005) highlights that subjective norm is significant in forecasting customer intention to engage with mobile banking and commerce. 


\section{Research Methodology}

A quantitative research methodology was used for this research. Self-administered quantitative questionnaires were distributed at the University of Witwatersrand as well as to individuals within the Johannesburg area aged between 18 and 60 years. A pilot study of 30 respondents was conducted to ensure validity and reliability of the questionnaire. Following this, the research was then conducted to a sample size of 373 respondents. Due to time constraints, this study made use of convenience sampling. Data collected from the questionnaires was analysed using statistical analysis to investigate the relationship between the variables used in the research model, this being a modified version of the Decomposed Theory of Planned Behaviour model - The decomposed TPB model is successful in predicting and explaining human behaviour across various platforms and breaking outcomes down into specific dimensions. In addition, the decomposed TPB model is most suitable for steering decision makers towards the implementation of innovations. The decomposed TPB model will provide insight into understanding consumers' individual attitudes, subjective norms and perceived behavioural control, which ultimately influences the likelihood of consumers using mbapps.

\section{Main Findings, Recommendations and Conclusion}

\subsubsection{First Finding}

The first finding relates to identifying the factors that drive consumers to adopt mbapps in the RSAn market. This study found that individually, attitude, perceived behavioural control and subjective norms constructs have significant relationships on the intention to adopt mbapps.

These construct findings are each discussed below:

\subsubsection{Attitude:}

It was found that the attitude towards the advantages of mbapps positively influence the intention to adopt a mbapps. This means that consumers are conclusively influenced by the degree to which the advantages of a mbapp offers the user. The findings portray that the greater the perceived advantages of using a mbapp, the more likely that mbapps will be adopted. That said, mbapps must provide value and benefits towards meeting the needs of its current day consumer.

It was found that the attitude towards risk \& privacy has a significant influence on the intention to adopt mbapps. It can therefore be said that consumers are concerned with the associated risk \& privacy of using a mbapp. As such, the higher the privacy and the lower the perceived risk associated with using mbapps, the more likely mbapps will be adopted. A need exists to provide consumers with the confidence that privacy is not a concern. This finding is supported by both Jaruwachirathanakul and Fink (2005) and Shambare (2013).

This study found that the attitude towards the features of mbapps, positively influence the intention of consumers to adopt a mbapp. As such, in order for banks to increase adoption rates and usage of a mbapp, banks need to ensure that consumers have a favourable attitude towards the features that a mbapp offers. To do this, banks need to provide features that would be of benefit to the consumer from a banking marketing perspective and in addition be easy to execute.

Collectively the three attitudinal factors that make up the attitude construct, do positively influence consumer intention to adopt a mbapp. This means that from an attitudinal perspective, consumers perception of the advantages, risks and privacy, as well as the preferred features, play a role in the adoption of mbapps.

\subsubsection{Perceived Behavioural Control:}

A positive relationship between self-efficacy and intention of consumers to adopt a application. As such, the greater the self-efficacy towards using a application, the more likely mbapps will be adopted by consumers. Banks need to make mbapps user friendly to increase a consumer's self-efficacy.

Similarly, a positive relationship exist between facilitating conditions and intention to adopt a mbapp. This means that not only do banks have to provide ease of access and affordability for consumers, but also need to ensure that cellular network providers provide the necessary infrastructure and bandwidth for ease of operation. Consequently, we can conclude from the results that the greater the facilitating conditions to mbapps, the more likely mbapps will be adopted.

The behavioural control construct, influences consumer intention to adopt a mbapp. 


\subsubsection{Subjective Norms:}

Subjective Norms (RSAn culture) do influence the adoption of mbapps. This means that RSAn consumers are influenced by the many cultures within the RSA population and more specifically around peer pressures from their social groups.

In summary of the first finding which aimed to identify the factors that drive consumers to adopt mbapps in the RSAn market, the above ultimately proves to be successful and influences consumer decision making, consumer behaviour and the factors that drive consumers to adopt mbapps from a RSAn market perspective.

\subsubsection{Second \& Third Finding}

The second finding relates to establishing a difference in adoption attitudes towards mbapps amongst different generations in the RSAn market (and if so why). This study only included those aged between 18 and 60 years. Therefore, the generations in this study include Generation $Y$ and Generation X. Generation $Y$ includes those aged from 18 to 35, whereas, Generation X includes those aged from 36 to 60 (Lamb et al., 2010).

The findings showed that age has a significant relationship on the intention to adopt mbapps (refer to table 4.24). This means that individuals of different ages are more likely to have different outcomes towards adopting mbapps. In addition, this finding identifies that $58 \%$ of Generation $Y$ respondents make use of a mbapp, whereas, only $46 \%$ of Generation $X$ respondents make use of a mbapp. Based on the above results it is evident that individuals from Generation $Y$ are more likely to adopt mbapps than Generation $X$. This is consistent with the findings in table 4.3 where the majority of those aged above 36 years (64\%) have indicated that they have not yet adopted mbapps. As a result, an opportunity is presented to potential marketers and bankers to direct their marketing strategies towards Generation $\mathrm{X}$ in order to increase adoption rates.

Having said this, t-test results in table 4.4 indicate that there was insufficient evidence to conclude that a meaningful difference in adoption attitudes towards mbapps amongst different generations in the RSAn market. In other words, the t-test results indicate that there is no significant difference in adoption attitudes towards mbapps amongst different generations in the RSAn market.

\subsubsection{Fourth Finding}

The final finding relates to establishing whether an intention to adopt mbapps by consumers in the RSAn market exists. This study found that all three constructs included in the proposed model, Attitude, Perceived Behavioural Control and Subjective Norms, all have a significant influence on the Intention to adopt Mbapps. From the findings we can therefore conclude, that all constructs included in the model, play a significant role on the intention to adopt a mbapp. In addition, there is intention to adopt mbapps by consumers in the RSAn market. Due to consumers having an interest to adopt mbapps offered by their banks, banks thus need to ensure these applications meet the sensitivity needs of its clients.

It is therefore interesting to compare this studies' findings, against those done both locally and aboard, which were completed from an internet or cell phone banking perspective and not from a mbapp perspective. A study conducted by Jaruwachirathanakul and Fink(2005) found that Thai consumers were influenced by only Attitude and Perceived Behavioural Control but not by Subjective Norms. This finding is similar to Shih and Fang (2004) done in Taiwan, where their findings, like Jaruwachirathanakul and Fink(2005), showed that Subjective Norms is not related to the Intention to Adopt. Interestingly,Shih and Fang(2004) results also exhibited low R-Squared results between linear regression factors. In addition, Brown et al.(2003) results in their study found that Subjective Norms have no significant relationship on ones Intention to Adopt. Lastly, a study done by Nasri(2011), agrees with this studies findings, of a significant relationship between the respondents' Attitude towards as well as Risk \& Privacy on the intention to adopt.

As emphasize by Shih and Fang(2004), there has been little research done that uses a decomposed Theory of Planned Behaviour model to discuss the intention to adopt new innovations. This study contributes to the understanding towards improving relationships that are included in the conceptual model. This studies finding's ultimately improves the understanding of these relationships and provides new knowledge for marketers, bankers and academics.

\subsection{Conclusion}

There has been a significant amount of development in the mobile banking arena in RSA and as a result financial institutions are constantly having to evolve in order to meet the needs of its consumers. Banks are also driven by shareholders who insist on respectable returns on their investments. This study therefore makes a contribution to the 
understanding what influences consumer behaviour and acceptance towards mbapp adoption in the RSAn market so as to ensuring that banks do evolve and shareholders do achieve their strategic imperatives.

This research included a comprehensive literature review, conducted a quantitative research study and performed the necessary statistical analyses into understanding and identifying consumer behaviour, acceptance and adoption strategies for mbapps in Johannesburg, RSA.

From the findings, it can be concluded that the results of this study support the proposed conceptual model. The findings of this research were focused towards, Attitude, Perceived Behavioural Control and Subjective Norms do have a relationship on the intention to adopt mbapps. In terms of the hypotheses set and tested, all resulted as postulated.

Africa is the second largest mobile market in the world in which RSA is the third largest country on the continent with the most mobile subscribers. More specifically, RSA has a mobile phone subscription penetration rate of over 100\% (Ber \& Sinha, 2012). Consequently, cell phone banking has proved successful over the years in RSA (Felix et al., 2012). From the findings it is evident that the emerging market of mbapps is steadily increasing, and has the potential along side regular cell phone banking to become the most widely used banking channel in years to come.

In conclusion to this study the contribution of this research provides decision makers with the factors that encourage consumers to adopt mbapps and to utilise the research to exploit the conversion rate of customers towards adopting mbapps. Lastly this study adds value to not only the RSAn market but potentially to other developing countries. It is recommended that decision makers take heed of the proposed strategies in maximising the rate of mbapp adoption.

\section{References}

Ajzen, I. (1985). From intentions to actions: A theory of planned behavior. J. Kuhl, \& J. Beckman (Eds.), Action-control: From cognition to behavior (pp. 11-39): Heidelberg: Springer.

Ajzen, I. (1991). The Theory of Planned Behavior. Organizational Behavior and Human Decision Processes, 50, 179-211.

Al-Khouri, A. (2013). Identity and Mobility in a Digital World. Technology and Investment, 04(01), 7-12. doi: 10.4236/ti.2013.41002

Alafeef, M., Singh, D., \& Ahmad, K. (2011). Influence of Demographic Factors on the Adoption Level of Mbapps in Jordan. Research Journal of Applied Sciences, 6(6), 373-377.

Amin, H. (2008). Factors affecting the intentions of customers in Malaysia to use mobile phone credit cards. Management Research News, 31(7), 493-503.

Bandura, A. (1977). Self-efficacy: toward a unifying theory of behavioral change. Psychological review, 84(2), 191.

Bandura, A. (1982). Self-efficacy mechanism in human agency. American psychologist, 37(2), 122.

Bank Administration Institute, B. (2012). BAI-Finacle Global Banking Innovation Awards 2012. http://www.bai.org/globalinnovations/ docs/misc documents 2012/global awards program post-(1).pdf?sfvrsn=2

Bauer, H. H., Barnes, S. J., Reichardt, T., \& Neumann, M. M. (2005). Driving Consumer Acceptance of Mobile Marketing: A Theoretical Framework and Empirical Study. Journal of Electronic Commerce Research, 6(3), 181-192.

Ber, G., \& Sinha, A. (2012). RSAn Mobile Generation. Study on RSAn Young People on Mobiles. http://www.unicef.org/ southafrica/SAF_resources_mobilegeneration.pdf

Brown, I., Cajee, Z., Davies, D., \& Stroebel, S. (2003). Cell phone banking: predictors of adoption in RSA—an exploratory study. International Journal of Information Management, 23(5), 381-394. doi: 10.1016/s0268-4012(03)00065-3

Chau, P. Y., \& Hu, P. J.-H. (2002). Investigating healthcare professionals' decisions to accept telemedicine technology: an empirical test of competing theories. Information \& management, 39(4), 297-311.

Chau, P. Y., \& Hu, P. J. H. (2001). Information technology acceptance by individual professionals: A model comparison approach*. Decision Sciences, 32(4), 699-719.

Crabbe, M., Standing, C., Standing, S., \& Karjaluoto, H. (2009). An adoption model for mobile banking in Ghana. International Journal of Mobile Communications, 7(5), 515-543.

Dapp, T. F., Stobbe, A., \& Wruuck, P. (2012). The Future of (mobile) Payments: New (online) Players Competing With Banks. Deutsche Bank Research, 1-32. http://www.dbresearch.com/PROD/DBR_INTERNET_EN-PROD/PROD0000000000298950/The+future+ of+(mobile)+payments\%3A+New+(online)+players+competing+with+banks.PDF

Davis, F. D. (1986). A technology acceptance model for empirically testing new end-user information systems: theory and results.

Davis, F. D. (1989). Perceived usefulness, perceived ease of use, and user acceptance of information technology. MIS Quarterly, 319340.

Davis., F. D., Bagozzi, R. P., \& Warshaw, P. R. (1989). User Acceptance of Computer Technology: A Comparison of two Theoretical Models. Management Science, 35(8), 982-1003.

Felix, B., Omolola, B., Irwin, B., \& Eric, C. (2012). Cell Phone Banking: Revisiting Predictors of Adoption in RSA.

First National Bank. (2012). Promotion Innovation. Retrieved 29 June, 2013, from https://http://www.fnb.co.za/innovation/index.html

Fishbein, M., \& Ajzen, I. (1975). Belief, attitude, intention and behavior: An introduction to theory and research. Reading: AddisonWesley.

Hill, T., Smith, N. D., \& Mann, M. F. (1986). Communicating innovations: Convincing computer phobics to adopt innovative technologies. Advances in Consumer Research, 13(1), 419-422. 
Holden, W., Dr. (2013). Mobile Commerce Markets: Sector-by-Sector Trend Analysis \& Forecasts 2013-2017 (pp. 126). Hampshire, England: Juniper Research Ltd.

Hutton, J. (2011). Mobile Phone Dominate in RSA. Mobile. Retrieved 1 July, 2013, from http://www.nielsen.com/us/en/newswire/ 2011/mobile-phones-dominate-in-south-africa.html

Ivatury, G., \& Pickens, M. (2006). Mobile Phone Banking and Low-Income Customers: Evidence from RSA. http://www.cgap.org/sites/ default/files/CGAP-Mobile-Phone-Banking-and-Low-Income-Customers-Evidence-from-South-Africa-Jan-2006.pdf

Jaruwachirathanakul, B., \& Fink, D. (2005). Internet banking adoption strategies for a developing country: the case of Thailand. Internet Research, 15(3), 295-311. doi: 10.1108/10662240510602708

Kamuti, T. (2013). The mobile revolution in Africa and conservation communication. Retrieved 19 July, 2013, from http://www. consultancyafrica.com/index.php?option=com_content\&view=article\&id=1271:the-mobile-revolution-in-africa-and-conservationcommunication\&catid=92:enviro-africa\&ltemid $=297$

Keshav, S. (2005). Why cell phones will dominate the future internet. ACM SIGCOMM Computer Communication Review, 35(2), 83-86.

Khalifa, M., \& Cheng, S. K. (2002). Adoption of mobile commerce: role of exposure. Paper presented at the PROCEEDINGS OF THE ANNUAL HAWAII INTERNATIONAL CONFERENCE ON SYSTEM SCIENCES.

Khraim, H. S., Shoubaki, Y., \& Khraim, A. S. (2011). Factors Affecting Jordanian Consumers' Adoption of Mobile Banking Services. International Journal of Business and Social Sciences, Volume No.

Laforet, S., \& Li, X. (2005). Consumers' attitudes towards online and mobile banking in China. International Journal of Bank Marketing, 23(5), 362-380.

Lamb, C. W., Jr., Hair, J. F., Jr., McDaniel, C., Boshoff, C., Terblanche, N., Elliott, R., \& Klopper, H. (2010). Marketing (4 ed.). Cape Town: Oxford University Press Southern Africa (Pty) Ltd.

Lascaris, R. (2012). RSA: More consumers use cellphones than listen to radio or watch TV. 2012(120). http://www.balancingactafrica.com/news/broadcast/issue-no120-0/broadcast/south-africa-more-co/bc

Laukkanen, T. (2007). Internet vs mobile banking: comparing customer value perceptions. Business Process Management Journal, 13(6), 788-797.

Laukkanen, T., Sinkkonen, S., Laukkanen, P., \& Kivijarvi, M. (2008). Segmenting bank customers by resistance to mobile banking. International Journal of Mobile Communications, 6(3), 309-320.

Lawack-Davids, V. (2012). The Legal and Regulatory Framework of Mobile Banking and Mobile Payments in RSA. Journal of International Commercial Law and Technology, 7(4), 318-327.

Lee, M. S., McGoldrick, P. J., Keeling, K. A., \& Doherty, J. (2003). Using ZMET to explore barriers to the adoption of 3G mobile banking services. International Journal of Retail \& Distribution Management, 31(6), 340-348.

Lee, S., Lee, S., \& Kim, Y. (2007). Factors influencing the adoption behavior of mobile banking: a South Korean perspective. Journal of Internet Banking and Commerce, 12(2), 1-9.

Luarn, P., \& Lin, H.-H. (2005). Toward an understanding of the behavioral intention to use mobile banking. Computers in Human Behavior, 21(6), 873-891.

Lutz, R. J. (1980). The role of attitude theory in marketing: University of California, Los Angeles, Center for Marketing Studies.

Maduku, D. K. (2012). Understanding retail bank customers' attitude towards and usage of cell phone and internet banking services in Gauteng, RSA.

Mail \& Guardian. (2011). Will the mobile wallet replace the leather wallet? Retrieved 1 July, 2013, from http://mg.co.za/article/2011-0518-will-the-mobile-wallet-replace-leather

Malhotra, N. K. (2005). Attitude and affect: new frontiers of research in the 21st century. Journal of business research, 58(4), 477-482.

Marti-Parreño, J., Sanz-Blas, S., Ruiz-Mafe, C., \& Aldás-Manzano, J. (2013). KEY FACTORS OF TEENAGERS'MOBILE ADVERTISING ACCEPTANCE. Industrial Management \& Data Systems, 113(5), 7-7.

McNeil, H. D. (2012). Older adults' perceptions of financial technologies. McMaster University. Retrieved from http://digitalcommons. mcmaster.ca/cgi/viewcontent.cgi?article=8508\&context=opendissertations\&sei-

redir=1\&referer=http\%3A\%2F\%2Fscholar.google.co.za\%2Fscholar\%3Fhl\%3Den\%26as_sdt\%3D0\%2C5\%26q\%3Dolder\%2Badul ts\%2Bperceptions\%2Bof\%2Bfinancial\%2Btechnologies-search=\%22older\%20adults\%20perceptions\%20financial\%20 technologies $\% 22$

Mlitwa, N., \& Tshetsha, N. (2012). Adoption of Cell-Phone Banking among Low-Income Communities in Rural Areas of RSA. iBusiness, 4.

Mogale, O. (2013). Mobile Banking Series: An overview of why mobile banking remains important for financial inclusion in Africa. Financial Services, Telecoms, KPMG. http://www.blog.kpmgafrica.com/mobile-banking-series-overview-why-mobile-bankingremains-important-financial-inclusion-africal

Nasri, W. (2011). Factors Influencing the Adoption of Internet Banking in Tunisia. International Journal of Business and Management, 6(8). doi: 10.5539/ijbm.v6n8p143

Ndubisi, N. O. (2004). Factors influencing e-learning adoption intention: Examining the determinant structure of the decomposed theory of planned behaviour constructs. Paper presented at the HERDSA International Conference Proceeding.

Ndubisi, N. O., \& Sinti, Q. (2006). Consumer attitudes, system's characteristics and internet banking adoption in Malaysia. Management Research News, 29(1/2), 16-27.

Ok, S.-j., \& Shon, J.-h. (2006). The determinant of Internet banking usage behavior in Korea: A comparison of two theoretical models.

Pedersen, P. E. (2005). Adoption of mobile Internet services: An exploratory study of mobile commerce early adopters. Journal of 
organizational computing and electronic commerce, 15(3), 203-222.

Pedersen, P. E., \& Ling, R. (2003). Modifying adoption research for mobile Internet service adoption: Cross-disciplinary interactions. Paper presented at the System Sciences, 2003. Proceedings of the 36th Annual Hawaii International Conference on.

Pikkarainen, T., Pikkarainen, K., Karjaluoto, H., \& Pahnila, S. (2004). Consumer acceptance of online banking: an extension of the technology acceptance model. Internet Research, 14(3), 224-235.

Polatoglu, V., \& Ekin, S. (2001). An empirical investigation of the Turkish consumers' acceptance of Internet banking services. International Journal of Bank Marketing, 19(4), 156-165.

Pousttchi, K., \& Schurig, M. (2007). Assessment of today's mbapps from the view of customer requirements. Paper presented at the System Sciences, 2004. Proceedings of the 37th Annual Hawaii International Conference on.

Power, D. J. (2013). Mobile decision support and business intelligence: an overview is. Journal of Decision Systems, 22(1), 4-9. doi: 10.1080/12460125.2012.760267

Pranata, I., Athauda, R., \& Skinner, G. (2013). Determining Trustworthiness and Quality of Mobile Applications Mobile Wireless Middleware, Operating Systems, and Applications (pp. 192-206): Springer.

Püschel, J., Mazzon, J. A., \& Hernandez, J. M. C. (2010). Mobile banking: proposition of an integrated adoption intention framework. International Journal of Bank Marketing, 28(5), 389-409.

Rodríguez-Ardura, I., Ryan, G., \& Gretzel, U. (2012). Special Issue on Qualitative Approaches to E-marketing and Online Consumer Behaviour: Guest Editors' Introduction.

Rogers, E. M. (1983). Diffusion of Innovations (Third ed.). New York: Free Press.

Schmidt, E., \& Cohen, J. (2013). The New Digital Age: Reshaping the Future of People, Nations and Business: Knopf Publishing Group.

Shambare, R. (2011). Cell phone banking adoption in RSA. Business and Economic Research, 1(1).

Shambare, R. (2013). Factors Influencing the Adoption of Cell Phone Banking by RSAn Students. African Journal of Business Management, 7(1), 30-38.

Shih, Y.-Y., \& Fang, K. (2004). The use of a decomposed theory of planned behavior to study Internet banking in Taiwan. Internet Research, 14(3), 213-223.

Statistics RSA. (2011). Census 2011. Statistics RSA Retrieved from http://www.statssa.gov.za/Publications/P03014/P030142011.pdf.

Sulaiman, A., Jaafar, N. I., \& Mohezar, S. (2007). An overview of mobile banking adoption among the urban community. International Journal of Mobile Communications, 5(2), 157-168.

Suoranta, M., \& Mattila, M. (2004). Mobile banking and consumer behaviour: new insights into the diffusion pattern. Journal of Financial Services Marketing, 8(4), 354-366.

Tan, M., \& Teo, T. (2000). Factors influencing the adoption of internet banking. Journal of Association for Information Systems, 1(5), 142.

Tashmia, I., \& Khumbula, M. (2011). Mobile banking: Innovation for the poor: United Nations University, Maastricht Economic and social Research and training centre on Innovation and Technology.

Taylor, S., \& Todd, P. (1995). Understanding Information Technology Usage: A Test of Competing Models. Information Systems Research, 6(2), 144-176.

The New Age. (2013). SA's 63 Million Cell Phone Users. Retrieved 25 June, 2013, from http://www.thenewage.co.za/93916-1007-53SAs_63_million_cell_phone_users

Tiwari, R., Buse, S., \& Herstatt, C. (2006). Mobile banking as business strategy: Impact of mobile technologies on customer behaviour and its implications for banks. Paper presented at the Technology Management for the Global Future, 2006. PICMET 2006.

Triandis, H. C. (1979). Values, attitudes, and interpersonal behavior. Paper presented at the Nebraska symposium on motivation.

Tubbs, B. (2012). RSAns and their cellphones. Retrieved 1 July, 2013, from http://www.itweb.co.za/index.php?option=com_ content\&view=article\&id $=57137$

Van Biljon, J., \& Kotzé, P. (2007). Modelling the factors that influence mobile phone adoption. Paper presented at the Proceedings of the 2007 annual research conference of the RSAn institute of computer scientists and information technologists on IT research in developing countries.

vander Meulen, R., \& Rivera, J. (2013). Gartner Says Worldwide Mobile Phone Sales Declined 1.7 Percent in 2012. 1. Retrieved 20 March, 2013, from http://www.gartner.com/newsroom/id/2335616

Virgillito, G., Personal Communication (2013, 2 July 2013). [Head of Banking Apps].

Wang, Y. S., Lin, H. H., \& Luarn, P. (2006). Predicting consumer intention to use mobile service. Information Systems Journal, 16(2), 157-179.

World Wide Worx. (2012). Mobility 2012. The Mobile Consumer in RSA 2012. http://www.worldwideworx.com/wp-content/uploads/ 2012/07/Exec-Summary-The-Mobile-Consumer-in-SA-2012.pdf 